УДК 811.161.2’373:398

С. А. Шуляк

\title{
МІФОСВІТ РОСЛИННИХ СИМВОЛІВ У ТЕКСТАХ УКРАЇНСЬКИХ ЗАМОВЛЯНЬ
}

Шуляк С. А. Міфосвіт рослинних символів у текстах українських замовлянь.

У статті аналізуються особливості функціонування та символічні значення лексики на позначення флоролексем у текстах українських замовлянь. Визначаються дикі та окультурені рослини у магічному просторі досліджуваних текстів. Розглядається семантика рослинних назв та їх трансформація у контексті в ролі атрибутів магічних істот та самостійних дійових осіб.

Ключові слова: текст, замовляння, символ, рослинні назви, флоролексема, міфосвіт, семантика.

(C) С. А. Шуляк, 2013. 
Шуляк С. А. Мифомир растительных символов в текстах украинских заговоров.

В статье анализируются особенности функционирования и символические значения лексики на обозначение флоролексем в текстах украинских заговоров. Определяются дикие и окультуренные растения в магическом пространстве исследуемых текстов. Рассматривается семантика растительных наименований и их трансформация в контексте в роли атрибутов магических существ и самостоятельных действующих лиц.

Ключевые слова: текст, заговоры, символ, растительные названия, флоролексема, мифомир, семантика.

Shulyak S. A. The mythoworld of flora symbols in the text of Ukrainian exorcisms.

Some functioning peculiarities and symbols meanings of the vocabulary on the marking of floralexemes in the Ukrainian exorcisms text are analyzed in the article. Some wild and cultivated plants in the magic space of the investigated texts are defined. Some meanings of the names of plants and their transformation into magic creatures attributes and independent characters are considered.

Key words: text, exorcism, symbol, the names of plants, floralexemes, mythoworld, semantics.

Дослідженню текстів замовлянь присвячені праці О. Потебні, Ф. Зелінського, Н. Познанського, М. Дмитренка, А. Астахової, О. Івановської. В. Петрова, В. Соколової, Т. Цив'ян, О. Свиридова, В. Харитонової, Ю. Мосенкіса, Н. Мечковської, О. Остроушко, О. Павлова та інших мовознавців.

Сьогодні дослідження українського фольклору як цілісної суб'єктнообразної системи 3 iï онтологічним статусом у загальнонаціональному культурному просторі $\epsilon$ актуальною складовою сучасного пізнання, частиною комунікативної компетенції; воно визначає механізми, прийоми і стратегії систематизації методів різних наук, інтегрування їх в єдиний фольклорно-теоретичний комплекс [2, с. 6].

Замовляння - це словесне порівняння спеціально кимось поробленого дійсного явища з бажаним явищем та примушення останнього здійснитися силою слова. А його призначення - вимагати позитивного, необхідного людині результату шляхом діалогу на рівних між знахарем та певною потойбічною силою у вигляді хвороби-духа [3, с. 17].

Серед безлічі магічних атрибутів замовлянь у цій статті зосередимо увагу на рослинній атрибутиці. У лінгвістичній науці досі немає одностайної думки щодо класифікації найменувань на позначення рослинних реалій. Тому існують такі терміни на позначення назв рослин: фітоніми, флоризми, флоролексеми, ботанізми, ботаноніми тощо. У нашому дослідженні вживатимемо термін флоролексема, який базується на семантиці слова флора, що позначає рослинний світ узагалі.

Метою цієї роботи є виявлення флоролексем, які функціонують у текстах українських замовлянь, і встановлення символічних значень досліджуваної лексики. Звертається увага на такі номени: ліс, луг, луки, cтеп, поле, болото, очерет, терен, бузина, дуб, верба, груша, рожа, васильки, дерево, плід, рослина, коріння.

Використання рослинної атрибутики є нічим іншим, як віддзеркаленням давнини міфосвіту замовлянь. Адже рослинна символіка походить від 
збирання корисних рослин: того етапу стосунків стародавньої людини 3 природою, який передував навіть мисливству; але збирання й пізніше довгий час лишалося джерелом «користі» (харчів, ліків, матеріалів для життя й побуту) [4, с. 231]. Тому дикі рослини (як і дикі тварини) в замовляннях істотно переважають над рослинами окультуреними. Так, «дуб» трапляється частіше від «дерева», «калина» - від «куща», «рута» - від «зілля» і т. ін.: конкретність і детальна розробленість кожної групи символів завжди прямо пропорційна їхній архаїчності [4, с. 232].

Ботанічні символи замовлянь можна розподілити на дві групи.

Дикі рослини. Дерева: дуб, береза, явір, верба. Кущі: купина, очерет, калина, малина, шипшина. Трави й квіти: рожа, рута, барвінок, васильок. Мохи (без конкретизації).

Окультурені рослини. Дерева: яблуня, груша. Кущів - немає. Злаки: пшениця, жито, ячмінь, гречка. Квітів - немає (мак присутній лише у зв' язку з насінням, не як квітка).

Розташовані рослини немов на межі ботаніки та географії замовлянь: ліс, гай, луг, болото, cmen, поле, нива [4, с. 233]. Так, у текстах українських замовлянь фіксуємо багато випадків уживання лексеми ліс: $B$ тебе в домі три панянки, вони не можуть ні иити, ні білити, тільки можуть намовки говорити. Пречиста Божа Мати, поможи мені намовки виганяти, на Осіянські гори, на ліси відсилати. Там Божа Мати ходила, Ісуса Христа за праву ручку водила, рабі Божій (ім'я) намовки відговорила [3, с. 25].

Ліс може бути чужим, як-от: Хай в дорозі його мій оберіг захищуає; щзоб гіркої води не напився, щуоб у лісі чужсому не заблудився, шоб об гострі кручі не розбився [3, с. 44]; сухим, наприклад: Iди [урочища] собi на сухий ліс, де соние не сходить, де курячий голос не заходить [3, с. 30]; Iди собі [пристріт], пий-гуляй, сухі лози ламай, а до Божої хрещеної (ім 'я) права не май. Із духом святим, із Господньою поміччю Матір Божа йшла, золотий обручик несла, голову стискала $і$ казала: - іди собі на сухий ліс [3, с. 27]; диким: Іәи [пристріт] на круті гори, на дикі ліса, там тобі буде од Господа Бога небеса. Водичкою переливайся, пісочком пересипайся, а до изього народженого, хрещеного (ім'я) більше ніколи не вертайся. [3, с. 29]; буйним: Було два брата й обидва Кіндрати. Один Христову молитву читає, а другий - переляк вимовляє, та на бистру воду і на буйний ліс одсилає. Годі, перелоги, у кості, у жилах стояти, червону кров пити $і$ гілля трощчити [3, с. 22]; чорним: У чорному лісі тобі, ляче, гуляти, а рабові Божсму (ім'я) ляку не знати [3, с. 22].

Лексеми луг, луки, cmen, хоч і не часто, але теж засвідчено в замовляннях: Орданська ріка, очищуаєи ти луги $i$ береги, очисть народженого, хрещеного (ім'я) од його болєзні! [3, с. 29]; Іила Христова Матуика з золотим хрестом, службу служити з Ісусом Христом. Бігла водиця з-під гір, з-під нижнніх лук. Я цүю водицюю набирала, з родженого (ім'я) всі хвороби Святим Духом виганяла [3, с. 19-20]; Завина водяна, завина вітрова, і стрітена, і в смак собі з їена, і в смак собі спитая.

(C) С. А. Шуляк, 2013. 
Піди собі на очерети, на дикі степи, на темні ліси [3, с. 63].

Усі символи пов'язані з вологими або багнистими місцями: болота, луги, купина, очерет, - або з місцями сухими, безплідними: степи, суха верба, колюча груша, - або особливо дикими (ліс), - утворюють «лихе царство» замовлянь, володіння хвороб, «гадин», хтонічних звірів, нечисті й шкоди. У сукупності своїй вони протистоять «нормальному» простору, в якому існують інші рослини [4, с. 234], як-от ліс, поле: Риба в морі, дуб у полі, а медвідь у лісі [3, с. 41]; Місяцьь на небі, медвідь у лісі, камінь у морі [3, с. 56]; Іәи собі [nристріт] на пусті ліси, на дикі поля, де птиці не залітають, де скоту не заганяють, де сокири не крешуть, де собаки не брешуть [3, с. 27]; Камінь - у морі, звір - у полі, а місяцьь - на небі [3, с. 58]; Звір - у полі, щука-риба - у морі, а місяцьь - на небі [3, с. 59]; Біс y полі, чорт у морі, диявол у вогні, а Місяцьь на небі [3, с. 66]; Зуби заговоряю, на біса складаю. Біс у лісі, а мрецьь у землі: як мрецьь стане пити, як мрець стане їсти, як стане вітра крутити, тоді буде в мене зуб боліти! [3, с. 67]; болото: Я тебе вишіптую, висікаю і на очерета й болота відправляю [3, с. 37]; Ураз-уразище, іди собі не болотище, тут тобі не панувати, білого тіла не псувати, червоної крові не марнувати [3, с. 65]; очерет: Іәи собі [nристріт] на очерета, на болота, там будеш розкошувати, розкоші мати, гнилі колоди жувати [3, с. 28]; Іди собі [nристріт] на очерета, на болота, там собі гуляй, і розкоші май, а до народженої раби Божої хрещеної (ім'я) діла не май! [3, с. 28]; Я тебе висилаю на очерета, на болота, там тобі накупатися, там тобі нагулятися, з братчиками повидатися [3, с. 69].

Зауважимо, що в текстах українських замовлянь чітко описано розташування флоролексем очерет та болото, де такий «пейзаж» несе психологічне навантаження i досить тонко передає гнітючий стан цих невеселих місць: Я тебе умоляю, я Божсии словами заклинаю, іди собі на очерета, на болота, де пташки не літають, де чоловічі ноги не ступають [3, с. 24]; у замовлянні від бешихи: Іди собі на очерета, на болота, де вітер не віє, де собаки не брешуть [3, с. 48]; Іди собі на очерета, на болота, де собаки не брешуть, півні не співають [3, с. 49]; Іди на очерета, на болота, де собаки не брешуть, де півні не співають, де кури не сокочуть, де пташки не літають, де люди не ходять [3, с. 65]. Функціонування текстів на кшталт: Поговорю уроки-урочища, з очей, з плечей, із рук, із ніг, з рум'яного лищя, $з$ щчирого серчя. Уроки дівочі, чоловічі, жсіночі, ідіть собі на очерета, де сонце не світить, де вітер не віє, де людського голосу не чути, де злий дух ходе. Тьху. $T_{b} x y . T_{b} x y[3$, c. 31] доводить помітну символічну взаємопроникність двох парадигм - флористичної та часу i простору. Традиційна семантика «незвичності», «таємничості» притаманна названим замовлянням, сприяє виникненню у структурі образів очерет і болото додаткового відтінку «страх».

Дуб - священне дерево слов'ян, германців, балтів, нерідко - синонім дерева взагалі, дерево предків, найпоширеніше втілення ідеї світового дерева, предмет спеціального культу. Серед замовних дерев веде 
безсумнівну першість. Ніколи не фігурує в утилітарній якості. Дуб у замовляннях - не так рослина, як місце, символ радше «топографічний», аніж ботанічний [4, с. 234]. Здебільшого дуб стоїть один; якщо ж він у множині, то йдеться завжди про магічне число: два, дванадиять, і ніколи не просто про «дуби» [4, с. 234]. Дуб ніколи й ніде не зображується у зловісному світлі. У дуба - найширша, універсальна влада над хворобами [4, с. 235]. Ці думки підтверджено такими текстами українських замовлянь: Там тобі бувати, там тобі розходжувати, там тобі з дуба листя чухмати, там тобі в (ім'я) костей не ламати [3, с. 35]; Вимовляла я й виговоряла, на Сіянські гори посилала, на Сиянських горах стоїть дуб на дванадияти воротях, нехай вони не ятряться, нехай вони од'ятруються [3, с. 31]; Поговору крові поганку. Іили три брати дуба рубати. Не пойдем дуба рубати, а пойдем гарячу кров зливати. 3 синіх жил, з жовтої кості, з чужої чорної масті [3, с. 56]; На морі, на білокомор'ї стояв дуб, під тим дубом лежав камінь, на тому камені - два парні сиділи [3, с. 57]; Місящь угорі, камінь на морі, а дуб-улісі [3, с. 58]; На полі-море, а в морі-дуб, а в дубі - яйе. Хто ией дуб зрубає $і$ піднесе, той мої зуби наврече [3, с. 59]; Місящь на небі, дуб у лісі, риба у воді. Якщо вони сядуть вечеряти разом, щоб молитвеному (ім'я) заболіли тоді зуби [3, с. 60]; На морі-океані стоїть дуб [3, с. 89]. Флоролексема дуб наділена такими епітетами: старий, зелений: Місяць на небі, старий дуб у полі, камінь у морі, мрець у землі. Коли вони всі прийдуть з одного корита воду пити, тоді будуть рабі Божій (ім'я) зуби боліти [3, с. 60]; Враз-вразище, добрий чоловічщще, устань під пупом, як під зеленим дубом. Тут тобі не бувати, червоної крові не пити, білого тіла не сушити [3, с. 64]; Дуб - більш архаїчний, а тому й універсальний, багатозначний і водночас позаетичний символ, не «добрий» $\mathrm{i}$ не «злий», а лише могутній, царствений і священний [4, с. 236].

У весняних язичницьких ритуалах (порівн. «вербна субота», «вербна неділя» християнської слов'янської обрядовості) верба - символ зростання, вона першою оживає навесні; нею шмагають, щоб спричинити за аналогією зростання дітей або худоби. Шмагають «до сліз»: сльози магічна подоба дощу; пролиття сліз забезпечує дощі на майбутні посіви, i водночас очищення від темних сил. Християнський ритуал переосмислив цю вербну магію у звичаї проливання сліз на жмут зелені для «змивання гріхів» [4, с. 237]. Символом помічного дерева верба виступає у наведеному далі контексті: Посеред двора стоїть верба, на тій вербі золота кора. Там три дівиці гуляли і оцюю кору лизали, а (ім'я) усякі поради уговоряли, сліди-послідки на Тихий океан відправляли, звідтіля (ім'я) здоров'я присилали [3, с. 29].

Груша може посідати таке ж центральне місце в моделі світу замовлянь, що й яблуня або дуб. Вона також стоїть посеред поля, іiі атрибут «золота кровать»; на ній володарка хтонічного царства, змія кропиня [4, с. 236]. Порівняно з яблунею, груша наочніше співвіднесена з антисвітом замовлянь: вона «колюча», асоціюється 3 сокирою та вогнем - символами (ㄱ С. А. Шуляк, 2013. $-647-$ 
нищення. Якщо дуб - це «першодерево» міфології замовлянь, то яблуня i груша - його варіації, одна у «світлий», «денний», друга - в «темний», «нічний» бік [4, с. 237]: Коло синього моря колюча груша стояла, під колючою грушою три пані сиділи. Одна - пише, друга - читає, третя крикси-ночниці зговоряє [3, с. 73]. М. К. Дмитренко зазначає, що груша символ світотворення (його темної частини), багатства, плодючості, дівчини, жінки; швидкоплинності буття; нещасливого кохання; оберіг [1, с. 139].

Найуживанішою квіткою в замовляннях виступає рожа. Неокресленість, «універсальність» цієї назви («ружею», «рожею» називають троянду, шипшину, мальву, іноді - руту, порівн. «червона рута»), а також атрибут, червоний колір. Рожа (ружа) - «червона квітка», «цар-квітка» архаїчної символіки. Рожа незмінно асоціюється з кров'ю [4, с. 239]: Рожс не зойшла, щуоб кров не пойшла [3, с. 54]; Заступила чорна хмара, з-за чорної хмари вийшли три янголи. Один - косить, другий - рубає, а третій кров замовляє. Іило три панни, всі три Ганни, сіять рожсу. Та рожса не зійшла, щуо так у раба Божсого (ім'я) кров з руки не йила [3, с. 55]; Йили три каліки, через три ріки, найшли золотий хрест, закопали у рожсу. Червона рожна не зійшла, шуоб з пальияя кров не йшла [3, с. 55]; Через три ріки, ішло три каліки. На синьому камені посіяли червону рожу. Червона рожса не зійшла, щуоб з пальцуя кров не йшла [3, с. 55].

Міцний запах - знак відміченості, тому всі пахучі трави (рута, м'ята, васильок та ін.) у світі замовлянь особливо магічні [4, с. 240]: Які ви (сояшниці) у світі не $\epsilon-$ то я вас ножем висікаю, веретеном викручую, на васильки виливаю, ложкою вибираю. Щезніть-пропадіть, де взялисьmуди й iдimb! [3, с. 69].

Калина серед символіки кущів посідає найпомітніше місце. «Калиновий міст» - поєднання, нелогічне для «реалістичного» мислення, яке цілком зрозуміле для мислення міфологічного. Його пояснювали (наприклад, В. Даль) як гатку, хмиз, яким мощено шлях через болота («міст»). Але міст і в прямому розумінні - перехід через межу, заповідну границю, місце зустрічі (інколи поєдинку) людини і «потойбічної», в прямому сенсі, магічної сили. Діставши ж незвичайний матеріальний атрибут («калиновий»), міст тим самим стає подвійно чудесним [4, с. 238]: Іиов Господь лісом, калиновим мостом. - Не думав я йти, а думав ӥхати на рижсому осляті до хрещеного (ім'я) чорного горя стишати. Лист осипається, а корінь чорного горя унічтожається [3, с. 25].

У текстах українських замовлянь засвідчено також лексеми, що тісно пов'язані з рослинною атрибутикою (дерево, плід, рослина, коріння, насіння), наприклад: Як небо створено з зірками і дерево зі своӥми плодами [3, с. 76]; Їхав чоловік стар, кінь під ним кар, по рослинах, по дорогах, по притонах, по містах [3, с. 52]; Добрий день, колодязь Абрам, земля Тетяна, вода Уляна. Прибуваєш ти з гір, із долин, із високих могил, обмиваєш ти каміннякреміння, на дереві креміння [3, с. 84]; Добридень тобі, вода Улияно! Прибува вода з усіх країв, з усього коріння, з усякого насіння. Так нехай у 
моєї скотини молоко прибува [3, с. 87]. У подібних текстах флористичні одиниці поєднуються 3 різними антропонімізаційними елементами, відтворюючи емоційно-одухотворені картини природи.

Серед кущових номінацій часто вживаним є слово бузина: - Добрий день тобі, зелена бузина, а щзо тобі вчора було? - Не було мені нічогісінько. За мною стариє, за мною малиє, за мною середніє, за мною передніє. Щоб я була красива і ясна, як те сонечко красне і ясне [3, с. 78]. Бузина (базник, чукчина) - кущ-тотем, ягоди чорні або червоні; символ нечистого, пов'язаного з чортом, місця, що має велику магічну силу впливу переважно негативного характеру [1, с. 162].

Одним із рослинних символообразів у текстах українських замовлянь є терновий кущ, як-от: ІӘу я до моря, по морю, а в морі - комора, стояв кущ терновий. А в тім кущі - лисичя четверо дітей навела. Як до тих лисищиних дітей ніщзо не пристане, так до родженого, хрещеного, молитвеного (ім'я) ніщз не пристане [3, с. 77]. Як зазначено у «Словнику символів», одна $з$ порід терну - диктам - отримала назву неопалимої купини. У перекладі $з$ церковнослов'янської купина означає «кущ». Цей терновий кущ виділяє своєрідні ефірні речовини, які можуть горіти, проте самої рослини вогонь не торкається. Ця дивовижна властивість не могла пройти непоміченою: вважалося, що з неопалимої купини виходить Бог, щоб показати людям істину. Пізніше ця легенда увійшла до Біблії, де розповідається, що вперше Бог явився Мойсею з неопалимої купини. В Україні з неопалимою купиною пов'язаний образ Богині-матері, а з прийняттям християнства - Діви Марії; образ незнищенної квітки життя [5, с. 120].

Отже, флоролексеми в текстах українських замовлянь характеризуються різноманітністю джерел свого походження, специфікою функціонування, широкою сферою вживання, своєрідними ознаками i властивостями, семантичним багатством. Зазвичай рослини $є$ атрибутами магічних істот, та лише зрідка самостійними дійовими особами. Подальшого дослідження потребують такі рослинні номінації: вишня, сосна, берест, береза, акація, клен, липа, осика, смерека, тополя, яблуня, жито, мох, лишайник, лози, трава, татарське зілля, барвінок, соняшник та інші.

\section{Література}

1. Дмитренко М. Символи українського фольклору : [монографія] / М. Дмитренко. - К. : УЦКД, 2011. - 400 с.

2. Івановська О. Український фольклор : семантика і прагматика традиційних смислів : [підручник] / О. Івановська. - К. : ВПК «Експрес-Поліграф», 2012. - 336 с.

3. Словесна магія українців / упоряд. В. Фісун. - К.: Вид-во «Бібліотека українця», 1998. - $103 \mathrm{c}$.

4. Українські замовляння / упоряд. Н. М. Москаленко ; автор передмови та коментаря М. О. Новикова. - К. : Дніпро, 1993. - 309 с.

5. Українські символи / за ред. М. К. Дмитренка. - К., 1994. - 141 с. 